\title{
Can Corporate Innovation Restrain the Stock Price Crash Risk?
}

\author{
Zhongpei Zhou, Dawei Pan \\ Management School, Jinan University, Guangzhou, China \\ Email: hfbz1109@163.com
}

How to cite this paper: Zhou, Z. P., \& Pan, D. W. (2018). Can Corporate Innovation Restrain the Stock Price Crash Risk? Journal of Financial Risk Management, 7, 39-54.

https://doi.org/10.4236/jfrm.2018.71003

Received: February 7, 2018

Accepted: March 19, 2018

Published: March 22, 2018

Copyright $\odot 2018$ by author and Scientific Research Publishing Inc. This work is licensed under the Creative Commons Attribution International License (CC BY 4.0).

http://creativecommons.org/licenses/by/4.0/

\section{cc (i) Open Access}

\begin{abstract}
Preventing the crash of stock prices and guaranteeing the steady of the capital market have become a significant issue when the strong supervision of financial risk becomes a consensus. Taking the A-share listed companies as research sample, this paper takes the enterprise innovation behavior into analysis framework of the stock price crash risk, and the study found that corporate innovation can curb the crash risk of stock price effectively, especially in the firm facing with strong financing constraints and the information transparency is equivocal. The research in this paper provides a new idea for the market value management of listed companies, and it also helps to control financial risks, maintain capital market stability; more importantly, it enriches the existing literature.
\end{abstract}

\section{Keywords}

Innovation, Stock Prices Crash Risk, Financing Constraints, External Supervision

\section{Introduction}

Preventing financial risks has become the top priority of market supervision since the 18th CPC National Congress. The state council's opinions on further promoting the healthy development of capital market point out that we will strive to maintain steady development of the capital market and encourage listed companies to establish market value management systems.

However, Huishan dairy (06863.HK) has become the focus of capital market, it Shares fell 90 percent in less than half an hour, falling from HK 2.81 dollar to HK 0.25 dollar and the evaporation in market value has been arrived at US $\$ 4$ billion since the most dramatic share price plunge in Hong Kong's recent history. The collapse in share prices is hardly alone. Other companies have suffered 
that like the God Fog department, Rongchuang in recent times or new Oriental, Jingdong company in 2016 etc., In 2015 there were more than 16 times large area drop stop phenomenon in A share. The collapse of the stock price has not only led to a sharp decline in the wealth of investors, but also has a serious impact on the operation of listed companies. Thus, it will greatly affect the smooth and orderly capital market. At the same time, economic development has entered a new normal, and innovation has entered the public view at the national strategic level. Then, the CPC central committee and the state council have formulated and implemented the outline and views on the development of innovation-driven development; therefore, corporate innovation's enthusiasm has also been greatly ignited.

There is a consensus that innovation is an important driving force of economic development. From the perspective of stock price collapse, we study the innovation behavior of enterprises and connect them. It is of great significance to discuss whether the innovation behavior of enterprises can restrain and prevent the stock price collapse. The influence factors and mechanism of stock price crash have been discussed systematically in some literatures. These documents suggest that the "bad news" accumulated by management in the context of information asymmetry. After reaching the limit, the "bad news" is released instantly. This has brought a huge shock to the capital markets, triggering a collapse in share prices (Luo \& Du, 2014; Xie et al., 2016). It also believes that the information on corporate innovation has an information content for capital markets (Lu \& Huang, 2009; Xin, 2009; Yao, 2013). But what is interesting is that few scholars have tied the R\&D innovation to the share price crash. This may have one reason that $\mathrm{R} \& \mathrm{D}$ innovation is considered to be a long, expensive activity at the enterprise level intuitively and it will increase short-term financial risk, and combined with the high degree of uncertainty associated with the expected return of enterprise innovation, so it is disgusted by cautious management and short-term investors (Jiang \& Wang, 2016; Li \& Zheng, 2016). However, we need to see that companies with innovative behaviors tend to gain more market attention. The innovative behavior of listed companies (Whether the patented technology is approved, whether the $\mathrm{R} \& \mathrm{D}$ project is progressing smoothly, the use of R\&D funds is compliance, and so on) as internal news naturally attracts investors' attention. The regulatory authorities require companies to fulfill the disclosure obligation of $\mathrm{R} \& \mathrm{D}$ information in the relevant policy documents of initial public offering and refinancing of enterprises. Accounting standards for enterprises also required companies to disclose relevant information. The disclosure of research and development information provides an effective channel for investors to make progress in innovation activities and the possibility of success and improve the transparency of the enterprise's information (Graham \& Rajgopal, 2005; Pietro \& Wagenhofer, 2014). There is a close connection between R\&D activities of enterprises and Disclosure of research and development information. It has important theoretical and literature significance that the link between enterprise R\&D behavior and the risk of stock price collapse can make 
up for the lack of knowledge about the innovation behavior of enterprises in the risk prevention of stock price collapse, and it also enriched the relevant literature on the economic consequences of enterprise innovation. Can the innovation of the enterprise reduce the risk of the share price collapse brought by management? How does enterprise research and development affect stock price crash risk? To solve this question, this paper takes the A-share listed company in China as a research sample from 2009 to 2015, and takes proxy variable of enterprise innovation behavior to observe and study influence of enterprise innovation behavior on the risk of stock price crash and its mechanism. The study found that enterprise's R\&D investment does significantly reduce the risk of a company's stock price crash and further group test shows that this low risk is more obvious when companies with an urgent need for research and development face strong financing constraints (non-state-owned enterprises and small-scale enterprises) and the bad external supervision environment of the enterprise (non-four audits, the legal environment is poor).

The research of this paper may have the following contributions. Firstly, this paper discusses the relationship between enterprise innovation behavior and the risk of stock price crash from the perspective of stock price collapse, and enriches and extends the risk of stock price crash and some literatures about the economic consequences of corporate innovation. Secondly, the research of this paper finds that the innovation behavior of enterprises can reduce the risk of stock price collapse and provide new ideas for the market value management of listed companies. It has important theoretical and practical effect that listed companies can achieve the goal of market value management through the choice of information on innovative behavior, because this can help to control the financial risk and maintain the stability of the capital market and it will also promote the steady implementation of the national innovation and development strategy.

\section{Literature Review and Research Hypothesis}

\subsection{Literature Review}

The research on the mechanism of stock price crash risk is mainly focused on information transparency (e.g., Jin \& Myers, 2006; Luo \& Du, 2014; Xie et al., 2016; Kim et al., 2011a, 2011b, 2016). They argue the "bad news" is released in a flash when the accumulation of "bad news" comes to its limit, resulting in a huge impact on capital market and the collapse of share price. The existing literature basically covers the information quality (Hutton et al., 2009; Kim et al., 2011a, 2016), various stakeholders such as management (Xu et al., 2014; Kim et al., 2011b; Li \& Liu, 2012), shareholder (Wang et al., 2015), analysts (Xu, 2012) and external factors such as institutional environment (Pan et al., 2011; Lin \& Zheng, 2016), media governance (Luo \& Du, 2014), etc. One of the basic ideas in academia for preventing and mitigating the stock price crash is to improve the company's information transparency and reduce the self-interest of management. For example, Lin \& Zheng (2016) finds that delisting supervision can 
eliminate negative information of dying enterprises and improve the information transparency of the market, thereby reducing stock price crash risk. Luo \& $\mathrm{Du}$ (2014) also find that frequent reports on listed companies significantly reduce the risk of future collapse of the company's stock price.

The literature on the economic consequences of enterprise $\mathrm{R} \& \mathrm{D}$ behavior is mainly focused on the following three aspects. 1) whether innovation investment can improve the innovation ability of the enterprise. It is generally believed that the enterprise innovation investment can improve the company's innovation performance. Pang \& Chen (2009) find that R\&D investment and patent output has a strong correlation. Others such as Wang et al. (2010), Zhang (2006), Xu et al. (2012) also find a positive correlation between R\&D input and innovation output. 2) whether innovation affects the enterprise value. And the relevant research has found the positive relationship between them. Zheng et al. (2016), Xu (2016) point out the number of patents in Chinese enterprises has a significant positive impact on the market value of listed companies, that is to say, corporate innovation behavior sends positive signals to investors. 3) the market reaction to the innovation behavior of enterprises. Theorists tend to think that enterprise innovation behavior can trigger corresponding market reaction. For example, Kelm, Narayanan, \& Pinches (1995) study the relationship between the two, and find that under the condition of asymmetric information, the whole market reaction would capture the initial announcement of $R \& D$ investment. Xiao (2007) finds that the market reaction of technical innovation investment announcement has obvious industry characteristics. Lu \& Huang (2009), Xin (2012) and Yao et al. (2013) also have found a positive relationship between $\mathrm{R} \& \mathrm{D}$ of similar enterprises and market reaction.

Through the above literatures, we can see that the existing research has a widely and useful discussion on the economic consequences of $R \& D$ behavior and the mechanism and prevention of stock price collapse. Interestingly, academic circles generally believe that information transparency will affect the risk of stock price crash. It is also considered that information about enterprise innovation is informative for capital market. However, few literatures have discussed the relationship between two factors of R\&D behavior and stock price crash risk. This is because research and development innovation, intuitively, is considered to be an investment activity with long cycle and high cost at the enterprise level. But it cannot be neglected that $\mathrm{R} \& \mathrm{D}$ activities are important internal messages of the company, which itself aggravates the information asymmetry behavior inside and outside the company (Qiao, 2003), and its related disclosure is a communicative bridge between companies and investors. With the increase of investment demand for research and innovation, it is necessary for us to discuss whether the company strengthens innovative behavior disclosure and whether investors and other stakeholders are more concerned with information related to the company, thus improving the corporate information environment and reducing the risk of stock price crash. 


\subsection{Research Hypothesis}

Disclosing information of $R \& D$ provides an efficient channel for investors to have access to the progress of corporations' latest activity and the possibility of its success and enhances corporations' information transparency (Graham, Harvey, \& Rajgopal, 2005; Pietro \& Wagenhofer, 2014). For those corporations with innovation in $R \& D$, their managers will have more related information released so as to distinguish themselves. Bhattacharya \& Ritter (1983) pointed that firms engaged in innovation would take advantage of patent as their signal in capital market to show their high quality. The research of Park (2015) also shows that those engaged in innovation will provide better financial reports so that information asymmetry can be reduced.

Besides, firms engaged in innovation turn to receive more attentions from the market. And those with investment in R\&D will be considered to have brighter market prospects because of psychological anticipation. Lerner \& Wulf (2007) pointed that venture capital often put patent as the prove of films' good management. The research of Hsu, Lee, Liu, \& Zhang (2015) found that innovation often indicates less default and capital cost. Because of the positive correlation between investment in $R \& D$ and innovation, expenditure on $R \& D$ is taken as an important reference of decision-making of venture capital, which, along with the unfixed investment in $\mathrm{R} \& \mathrm{D}$, leads to more attention to related information disclosure from some stakeholders such as analysts, investors, auditors and press. The research of Barth, Kasznik, \& McNichols (2002) pointed out that analysts will pay more attention to firms engaged in innovation than those with less or without innovation. And the research of Xie \& Ai (2014) Chunrong also found that the "interpretation mechanism", to which analysts pay much attention, can reduce information asymmetry so as to positively influence a firm's input into $\mathrm{R} \& \mathrm{D}$. In addition, the more information transparency, the less asymmetry, which can prevent firms from keeping shares for later sales for purpose of getting more benefits. As a result of that, stock price crash risk brought by that can be reduced. Based on discussion above, hypothesis 1 is given.

Hypothesis 1: There is a negative correlation between films' input in R\&D and share crashing.

In the background of Chinese social system, finance is developed unevenly and the structural imbalance of credit is acute (Li \& Zhang, 2009). Constrained by some social bias, private enterprises are more difficult to raise fund compared with state-owned enterprises who often enjoy favorable policy of credit from banks (Li \& Liu, 2009 , Wei et al., 2014). In addition, small and medium-sized enterprises are inclined to get mired in the difficulties of fundraising as a result of their short history, less collateral and high friction cost in financial market (Almeida et al., 2004). Under that circumstance, when in dire need of capital for $\mathrm{R} \& \mathrm{D}$, small and medium-sized enterprises will disclose much more related information to win the trust of investors. At the same time, some exterior stakeholders such as press and analysts will search for more information of those en- 
terprises, which will reduce information asymmetry and thus lower the risk of share crashing. Based on this, hypothesis 2 is proposed.

Hypothesis 2: In face with many constraints in raising funds, more input in $\mathrm{R} \& \mathrm{D}$ leads to less risk of share price collapse.

Regulators will impose limits on managers of a firm. Effective social regulations will make it less free for managers of films to manipulate information (Zhang et al., 2017). If there is little regulations from society, films will be considered as being lack of information transparency. Investors require more information to judge a firm. Otherwise, the silence of management will be regarded as concealing inside information, which will cause values loss of the firm. As a result of that, management of firms with input in R\&D will have to release more information so that the risk of share crashing can be reduced. Based on that, the hypothesis 3 is proposed.

Hypothesis 3: When there is weak supervision from external environment, the more input into $R \& D$, the less risk of share crashing.

In the following parts, we will collect samples and data and use OLS empirical analysis to verify our hypotheses.

\section{Research Design}

\subsection{Samples and Data Sources}

A-share listed companies in Shanghai and Shenzhen stock markets from 2009 to 2015 are chosen as the object of the research with financial enterprises. We exclude listed firms 1) in financial industry 2) with annual observation going public less than a year 3) with data losing. And the final samples are 12,615 annual observations from 2327 firms. Given the effect of outliers, $1 \%$ and $99 \%$ winsorization are given to continuous variable, based on which is the following descriptive statistics and the report of empirical results. And the data of companies' expenditure on $R \& D$, market return rate, return rate of individual share and financial figures in this dissertation come from CSMAR ${ }^{1}$. The statistical software Stata 13 is used in the empirical analysis.

\subsection{Design of the Model}

On the basis of the purpose of the research, the model is designed as follow with reference to existing documents (Jiang \& Xu, 2015; Ma et al., 2016; Hamdi et al., 2017):

$$
\text { Crash Risk }_{i, t}=\partial_{0}+\partial_{1} * R \& D_{i, t}+\partial_{2} * \operatorname{Control}_{i, t}+\varepsilon_{i, t}
$$

where Crash Risk ${ }_{i, t}$ is the possibility of share price collapse of firm $i$ in the year of $t$ (including NCSKEW, Crash). $R \& D_{i, t}$ is the expenditure on R\&D of the firm in ${ }^{1}$ CSMAR database is developed specifically for Chinese financial and economic field research, including 75 sub-databases in 11 series such as stock market, company research, fund market, bond market, derivative market, economic research, industry research, overseas study and monographic study. 
the year of $t$. And Control represents control variables, while $\varepsilon_{i, t}$ random disturbance.

\subsection{Variable Definition}

\subsubsection{Share Price Crash}

Referring to approaches used by Xu et al. (2012), Wang et al. (2015), Jiang \& Xu in 2015, two ways are employed to measure the risk of share price collapse as follows:

First, model (2) below is used to remove market factors' influence on the return rate of individual share, which is to estimate the share price collapse of listed companies with residuals gotten by the regression of model (2). $\varepsilon_{i, t}$ the residual, represents the fluctuation of individual share which is inconsistence with market return rate.

$$
r_{i, t}=\beta_{i}+\beta_{1} * r_{M, t-2}+\beta_{2} * r_{M, t-1}+\beta_{3} * r_{M, t}+\beta_{4} * r_{M, t+1}+\beta_{5} * r_{M, t+2}+\varepsilon_{i, t}
$$

In equilibrium, $r_{i, t}$ is the stock return of firm $i$ in the week of $\mathrm{t}$ and $r_{M, t}$ is the weighted average return rate of market in the week of $\mathrm{t}$. And then $W_{i, t}$ the specific return rate of a week according to the equilibrium- $W_{i, t}=\ln \left(1+\varepsilon_{i, t}\right)$. And there is one thing you should know. In order to reduce look-ahead bias to ensure the availability of financial data of investors, the transaction from May every year to April of next year is put as a sample of annual assessment.

Referring to the research of Xu et al. (2012), Wang et al. (2015), the first index used to measure stock price crash risk is negative skewness of return rate (NCSKEW), which can be calculated by formula (3) where $\mathrm{n}$ is the number of week of $i$ share's transaction in the year of $t$. A larger NCSKEW represents a greater extent of negative skewness of return rate, which means more risk of stock crash.

$$
N C S K E W_{i, t}=-\left[n(n-1)^{3 / 2} \sum W_{i, t}^{3}\right] /\left[(n-1)(n-2)\left(\sum W_{i, t}^{2}\right)^{3 / 2}\right]
$$

Referring to the research of Jiang Xuanyu and Xu Nianhang, etc., the second index is the number of stock crash in the very year (Crash). If the specific weekly return of individual share of a year can satisfy the equation below for at least one time, the Crash will be 1 , otherwise 0 .

$$
W_{i, t} \leq \text { Average }\left(W_{i, t}\right)-3.09 * \delta
$$

In equilibrium, Average $\left(W_{i, t}\right)$ is the average of specific weekly return of firm $i$ in a certain year. And $\delta$ is the standard deviation of specific weekly returns of firm $i$ in that year.

\subsubsection{R\&D of Enterprises}

With reference to the researches of Tang et al. (2012), Wu \& Tang (2016), napierian logarithm of expenditure on $R \& D$ is taken as substitute variable of $R \& D$.

\subsubsection{Other Control Variables}

Referring to the documents of Chu \& Fang (2016) and Xie et al. (2016) the fol- 
lowing variables are controlled: excess turnover rate of share (RturnSd), annual average of specific weekly return rate (RetFirmAvg), standard deviation of a firm's weekly return rate of a year (Sigma), the size of a firm (Size), asset-liability ratio (Lev), the proportion of a firm's book value to market value(BM), return on asset (ROA), non-transparency of information (AbsDa) and the previous negative skewness of share's return rate or if there is a crash (NCSKEW_Last/Crash_Last), which can be seen in Table 1.

\section{Empirical Analysis}

\subsection{Descriptive Statistics}

The descriptive statistics of all variables are listed in Table 2. From the table, we can see that the average of NCSKEW and Crash are -0.34 and 0.08 and standard deviation of them are 0.63 and 0.28 respectively, which indicates great difference among firms of which the highest NCSKEW is 1.20 , while the lowest is -2.17 . The average of $\mathrm{R} \& \mathrm{D}$ is 9.89 , indicating that those firms' average expenditure on $\mathrm{R} \& \mathrm{D}$ in a year during the sample period is 19.7 thousand yuan $\left(\mathrm{e}^{9.89}\right)$. The most expenditure on R\&D can reach 996.70 thousand yuan, which is totally different from those without input in $\mathrm{R} \& \mathrm{D}$ (standard deviation is 8.72). In addition, we can see from the table that all control variables are within a reasonable range.

\subsection{Correlation Analysis}

The analyses of major variables with Pearson Correlation Coefficient are listed in Table 3. We can see that there is an obvious correlation between NCSKEW, Crash, the two index of stock crash and $\mathrm{R} \& \mathrm{D}$, major control variables. The

Table 1. Definition of major variables.

\begin{tabular}{|c|c|c|}
\hline Variable type & Variable name & Definition of major variables \\
\hline \multirow{2}{*}{$\begin{array}{l}\text { Explained } \\
\text { variables }\end{array}$} & NCSKEW & Negative skewness of share' s return rate in the year of $t$. \\
\hline & Crash & If there is any stock crash of a firm in the year of $t$. \\
\hline \multirow[t]{4}{*}{$\begin{array}{l}\text { Explaining } \\
\text { variable }\end{array}$} & $\mathrm{R} \& \mathrm{D}$ & $\begin{array}{l}\text { Tthenapierian logarithm is gotten by adding } 1 \text { to firm's } \\
\text { expenditure on R\&D. }\end{array}$ \\
\hline & RturnSd & The excess turnover rate of share I in the year of $t$. \\
\hline & RetFirmAvg & $\begin{array}{l}\text { The annual average of specific weekly return rate of share } I \text { in the } \\
\text { year of } t \text {. }\end{array}$ \\
\hline & Sigma & $\begin{array}{l}\text { The annual standard deviation of specific weekly return rate of } \\
\text { share I in the year of } t \text {. }\end{array}$ \\
\hline \multirow{5}{*}{$\begin{array}{l}\text { Control } \\
\text { variables }\end{array}$} & Size & The size of a firm, napierian logarithm of total assets. \\
\hline & Lev & Asset-liability ratio. \\
\hline & $\mathrm{BM}$ & The proportion of a firm's book value to market value. \\
\hline & ROA & $\begin{array}{l}\text { Return on total assets which is gotten by dividing net profit by the } \\
\text { total assets at year end. }\end{array}$ \\
\hline & AbsDa & The accrued profit calculated with modified Jones model. \\
\hline
\end{tabular}


Table 2. Summary statistics.

\begin{tabular}{ccccccc}
\hline VARIABLES & $\mathrm{N}$ & mean & $\mathrm{sd}$ & $\mathrm{min}$ & $\mathrm{p} 50$ & $\max$ \\
\hline NCSKEW & 12,615 & -0.336 & 0.633 & -2.170 & -0.301 & 1.202 \\
Crash & 12,615 & 0.0821 & 0.275 & 0 & 0 & 1 \\
R\&D & 12,615 & 9.891 & 8.724 & 0 & 16.00 & 20.72 \\
RturnSd & 12,615 & -0.0124 & 0.330 & -1.177 & 0.00480 & 0.880 \\
RetFirmAvg & 12,615 & 0.0222 & 0.0415 & -0.0491 & 0.0152 & 0.155 \\
Sigma & 12,615 & 0.0469 & 0.0159 & 0.0186 & 0.0445 & 0.0990 \\
Size & 12,615 & 21.90 & 1.237 & 19.12 & 21.76 & 25.68 \\
Lev & 12,615 & 0.463 & 0.223 & 0.0475 & 0.463 & 1.025 \\
BM & 12,615 & 0.904 & 0.887 & 0.0729 & 0.613 & 5.301 \\
ROA & 12,615 & 0.0402 & 0.0597 & -0.199 & 0.0361 & 0.228 \\
AbsDa & 12,615 & 0.114 & 0.144 & 0.00140 & 0.0740 & 1.074 \\
\hline
\end{tabular}

Table 3. The pearson correlation for main variables.

\begin{tabular}{ccccccc}
\hline VARIABLES & NCSKEW & Crash & R\&D & RturnSd & RetFirmAvg & Sigma \\
\hline NCSKEW & 1 & & & & & \\
Crash & $0.431^{* * *}$ & 1 & & & & \\
R\&D & $-0.037^{* * *}$ & $-0.036^{* * *}$ & 1 & & & \\
RturnSd & $-0.098^{* * *}$ & $-0.035^{* * *}$ & $0.085^{* * *}$ & 1 & & \\
RetFirmAvg & $-0.116^{* * *}$ & $-0.110^{* * *}$ & $0.109^{* * *}$ & $0.304^{* * *}$ & 1 & \\
Sigma & $-0.074^{* * *}$ & -0.005 & $0.087^{* * *}$ & $0.361^{* * *}$ & $0.380^{* * *}$ & 1 \\
\hline
\end{tabular}

${ }^{* * *},{ }^{* *}$ and ${ }^{*}$ represent statistical significance at the $1 \%, 5 \%$ and $10 \%$, respectively.

correlation coefficient between R\&D and NCSKEW, Crash are respectively -0.037 and -0.036 , both of which are higher than $1 \%$, the significance level. This is consistent with hypothesis 1 that more input in $\mathrm{R} \& \mathrm{D}$ can reduce stock price crash risk without control over other factors. All of the correlation coefficients between variables are lower than 0.5 without multicollinearity.

\subsection{Regression Analysis}

\subsubsection{Firms' Input in Innovation and Stock Price Crash Risk}

The empirical results of firms' input in innovation and risk of stock crash are listed in Table 4. NCSKEW is employed as the index of stock price crash risk in regression (la) (lb). With the index of Year Industry under control, the coefficient of R\&D is -0.0038 . When all the index that influence stock price crash risk are kept under control, the coefficient of R\&D is -0.0029 and obvious at the significance level of $1 \%$. In regression (2a) (2b), the regression results of Crash are below when variables are controlled or not, which are respectively -0.0114 at the level of $1 \%$ and -0.120 at the level of $5 \%$. That implies that more input in innovation can reduce stock price crash risk, demonstrating hypothesis 1 . With 
Table 4. Firms' input in innovation and stock price crash risk.

\begin{tabular}{|c|c|c|c|c|}
\hline \multirow{2}{*}{$\begin{array}{c}\text { VARIABLES } \\
\text { Models }\end{array}$} & \multicolumn{2}{|c|}{ NCSKEW } & \multicolumn{2}{|c|}{ Crash } \\
\hline & (1a) & (1b) & (2a) & (2b) \\
\hline \multirow[t]{2}{*}{$\mathrm{R} \& \mathrm{D}$} & $-0.0038^{\star * *}$ & $-0.0029^{* * *}$ & $-0.0146^{\star * *}$ & $-0.0120^{\star *}$ \\
\hline & $(-4.23)$ & $(-3.18)$ & $(-2.75)$ & $(-2.21)$ \\
\hline \multirow[t]{2}{*}{ RturnSd } & & $-0.0941^{\star * *}$ & & 0.1263 \\
\hline & & $(-4.72)$ & & $(1.00)$ \\
\hline \multirow[t]{2}{*}{ RetFirmAvg } & & $-1.4008^{\star * *}$ & & $-18.9172^{\star * *}$ \\
\hline & & $(-6.27)$ & & $(-12.22)$ \\
\hline \multirow[t]{2}{*}{ Sigma } & & $-5.7328^{\star * *}$ & & $16.6559^{* * *}$ \\
\hline & & $(-11.39)$ & & $(5.54)$ \\
\hline \multirow[t]{2}{*}{ Size } & & $-0.0220^{* * *}$ & & $-0.0934^{\star *}$ \\
\hline & & $(-3.23)$ & & $(-2.19)$ \\
\hline \multirow[t]{2}{*}{ Lev } & & $0.2822^{* * *}$ & & -0.2325 \\
\hline & & $(8.17)$ & & $(-1.12)$ \\
\hline \multirow[t]{2}{*}{$\mathrm{BM}$} & & $-0.0856^{* * *}$ & & $0.1524^{\star *}$ \\
\hline & & $(-8.47)$ & & $(2.58)$ \\
\hline \multirow[t]{2}{*}{ ROA } & & 0.1114 & & -0.3412 \\
\hline & & $(1.00)$ & & $(-0.51)$ \\
\hline \multirow[t]{2}{*}{$\mathrm{AbsDa}$} & & $0.1496^{* * *}$ & & 0.0144 \\
\hline & & $(3.76)$ & & $(0.06)$ \\
\hline \multirow[t]{2}{*}{ Crash_Last/NCSKEW_Last } & & $0.0634^{\star * *}$ & & $0.2307^{\star *}$ \\
\hline & & $(7.15)$ & & $(2.03)$ \\
\hline Year、Industry & Yes & Yes & Yes & Yes \\
\hline \multirow[t]{2}{*}{ Constant } & $-0.3790^{\star * \star}$ & $0.3059^{\star *}$ & $-3.0344^{\star * *}$ & -1.1497 \\
\hline & $(-8.40)$ & $(2.05)$ & $(-11.21)$ & $(-1.22)$ \\
\hline Observations & 12,615 & 12,615 & 12,610 & 12,610 \\
\hline Adj. R2(r2_p) & 0.0315 & 0.0708 & 0.0331 & 0.0586 \\
\hline
\end{tabular}

T values in parentheses, ${ }^{* * *},{ }^{* *}$ and ${ }^{*}$ represent statistical significance at the $1 \%, 5 \%$ and $10 \%$, respectively.

respect to control variables, RetFirmAvgand Size are markedly below zero, while NCSKEW_Last/Crash_Last is above zero, which is consistent with existing documents Chu \& Fang (2016) and Xie et al. (2016).

\subsubsection{Financing Constraints, Firms' Input in Innovation and Stock Price Crash Risk}

As mentioned above, China's small and medium-sized enterprises are often confronted with more constraints when raising funds. Therefore, the nature of property right and its size are taken as grouping variables of financing constraints.

The regression analysis results of financing constraints, firms' input in inno- 
vation and stock price crash risk are listed in Table 5. Models (1b) (2b) of Panel A show that there is obvious negative correlation between input in $R \& D$ and stock price crash risk, of which the regression coefficient are -0.0043 and -0.0154 respectively ( $t$ is -3.17 and -1.94 ), in the subsamples of private enterprises. On the contrary, the testing result of input in R\&D and stock price crash risk in state-owned enterprises samples is not statistically significant. And the regression analysis result of (1b) (2b) of Panel B implies that there is an obvious negative correlation between input in $\mathrm{R} \& \mathrm{D}$ and stock price crash risk, of which the regression coefficient are respectively -0.0045 at the significance level of $1 \%$ and -0.0145 at the significance level of $10 \%$, in small companies. That means when a firm which requires capital for R\&D is confronted with financing constraints, its management is inclined to disclose more related information to win the trust of investors and boost their confidence, which in turn will improve information transparency and thus reduce stock price crash risk. The hypothesis 2 , therefore, is demonstrated.

Table 5. Financing constraints, firms' input in innovation and stock price crash risk.

\begin{tabular}{|c|c|c|c|c|}
\hline \multicolumn{5}{|c|}{ Panel A Firms' Input in Innovation and stock price crash risk—distinguish property rights } \\
\hline \multirow{2}{*}{$\begin{array}{c}\text { VARIABLES } \\
\text { Models }\end{array}$} & \multicolumn{2}{|c|}{ NCSKEW } & \multicolumn{2}{|c|}{ Crash } \\
\hline & (1a) & (1b) & (2a) & $(2 b)$ \\
\hline Groups & State-owned & Non State-owned & State-owned & Non State-owned \\
\hline \multirow[t]{2}{*}{$\mathrm{R} \& \mathrm{D}$} & -0.0020 & $-0.0043^{* * *}$ & -0.0108 & $-0.0154^{*}$ \\
\hline & $(-1.54)$ & $(-3.17)$ & $(-1.34)$ & $(-1.94)$ \\
\hline $\mathrm{CV}$ & YES & YES & YES & YES \\
\hline \multirow[t]{2}{*}{ Constant } & $0.7756^{* * *}$ & -0.2930 & 0.2877 & $-2.4772^{*}$ \\
\hline & $(3.50)$ & $(-1.35)$ & $(0.21)$ & $(-1.75)$ \\
\hline Observations & 5777 & 6838 & 5744 & 6730 \\
\hline Adj. R2(r2_p) & 0.0928 & 0.0567 & 0.0611 & 0.0671 \\
\hline \multicolumn{5}{|c|}{ Panel BFirms' Input in Innovation and stock price crash risk—distinguish size } \\
\hline VARIABLES & \multicolumn{2}{|c|}{ NCSKEW } & \multicolumn{2}{|c|}{ Crash } \\
\hline Models & (1a) & (1b) & (2a) & (2b) \\
\hline Groups & Big Size & Small Size & Big Size & Small Size \\
\hline \multirow[t]{2}{*}{$\mathrm{R} \& \mathrm{D}$} & 0.0001 & $-0.0045^{\star * \star}$ & -0.0050 & $-0.0145^{\star}$ \\
\hline & {$[0.08]$} & {$[-3.20]$} & {$[-0.66]$} & {$[-1.67]$} \\
\hline $\mathrm{CV}$ & YES & YES & YES & YES \\
\hline \multirow[t]{2}{*}{ Constant } & -0.0296 & $0.8841^{\star * *}$ & 0.4286 & $4.5655^{\star *}$ \\
\hline & {$[-0.12]$} & {$[2.58]$} & {$[0.26]$} & [2.13] \\
\hline Observations & 6483 & 6132 & 6405 & 6125 \\
\hline Adj. R2 & 0.078 & 0.090 & 0.0685 & 0.0641 \\
\hline
\end{tabular}

T values in parentheses, ${ }^{* * *},{ }^{* *}$ and ${ }^{*}$ represent statistical significance at the $1 \%, 5 \%$ and $10 \%$, respectively. 


\subsubsection{External Supervision, Firms' Input in Innovation and Stock Price Crash Risk}

In this dissertation, the audit of the Big Four and if A share and B share or $\mathrm{H}$ share come into the market simultaneously are employed as the grouping variables of external supervision. And the regression analysis results of input in $\mathrm{R} \& \mathrm{D}$ and stock price crash risk in different external supervision environment are listed in Table 6. Pane A is grouped according to the supervision of auditors, while Panel B according to legal environment. In the subsamples of the group without the audit of the Big Four in Panel A, there is an obvious negative correlation between firms' input in $R \& D$ and stock price crash risk, of which the regression coefficients are respectively -0.0030 and -0.0107 . On the contrary, there is no obvious negative correlation between firms' input in R\&D and stock price crash risk in the subsamples of the group with audit from the Big Four. And the regression analysis result in Panel B is similar to that of Panel A. That means when there is little external supervision, manager of a firm, in order to

Table 6. External supervision, firms' input in innovation and stock price crash risk.

\begin{tabular}{|c|c|c|c|c|}
\hline \multicolumn{5}{|c|}{ Panel A: Firms' Input in Innovation and stock price crash risk—distinguish auditor supervision } \\
\hline \multirow{2}{*}{$\begin{array}{c}\text { VARIABLES } \\
\text { Models }\end{array}$} & \multicolumn{2}{|c|}{ NCSKEW } & \multicolumn{2}{|c|}{ Crash } \\
\hline & (1a) & (1b) & (2a) & $(2 b)$ \\
\hline Groups & Big 4 & Not Big 4 & Big 4 & Not Big 4 \\
\hline \multirow[t]{2}{*}{$\mathrm{R} \& \mathrm{D}$} & 0.0020 & $-0.0030^{* * *}$ & -0.0310 & $-0.0107^{*}$ \\
\hline & $(0.44)$ & $(-3.16)$ & $(-0.96)$ & $(-1.87)$ \\
\hline $\mathrm{CV}$ & YES & YES & YES & YES \\
\hline \multirow[t]{2}{*}{ Constant } & -0.0294 & $0.3052^{*}$ & 4.1147 & -1.1306 \\
\hline & $(-0.05)$ & $(1.90)$ & $(0.79)$ & $(-1.12)$ \\
\hline Observations & 593 & 12,022 & 506 & 12,017 \\
\hline Adj. R2 & 0.0975 & 0.0696 & 0.151 & 0.0591 \\
\hline \multicolumn{5}{|c|}{ Panel B: Firms' Input in Innovation and stock price crash risk-distinguish legal environment } \\
\hline VARIABLES & \multicolumn{2}{|c|}{ NCSKEW } & \multicolumn{2}{|c|}{ Crash } \\
\hline Models & (1a) & (1b) & (2a) & (2b) \\
\hline Groups & $\begin{array}{c}\text { Good legal } \\
\text { environment }\end{array}$ & $\begin{array}{c}\text { Bad legal } \\
\text { environment }\end{array}$ & $\begin{array}{c}\text { Good legal } \\
\text { environment }\end{array}$ & $\begin{array}{c}\text { Bad legal } \\
\text { environment }\end{array}$ \\
\hline \multirow[t]{2}{*}{$\mathrm{R} \& \mathrm{D}$} & 0.0036 & $-0.0035^{\star * *}$ & -0.0191 & $-0.0118^{* *}$ \\
\hline & $(0.97)$ & $(-3.65)$ & $(-0.77)$ & $(-2.05)$ \\
\hline $\mathrm{CV}$ & YES & YES & YES & YES \\
\hline \multirow[t]{2}{*}{ Constant } & -0.1448 & $0.2727^{*}$ & -3.5089 & -1.2301 \\
\hline & $(-0.25)$ & (1.69) & $(-0.81)$ & $(-1.22)$ \\
\hline Observations & 799 & 11,816 & 626 & 11,811 \\
\hline Adj. R2 & 0.112 & 0.0690 & 0.123 & 0.0590 \\
\hline
\end{tabular}

T values in parentheses, ${ }^{* * *},{ }^{* *}$ and ${ }^{*}$ represent statistical significance at the $1 \%, 5 \%$ and $10 \%$, respectively. 
improve the firm's image, will release more information about their R\&D to attract investors, which will improve information transparency and thus reduce stock price crash risk. And the hypothesis 3 is demonstrated by that.

\subsection{Robustness Examination}

In order to ensure the reliability of the empirical results, some robustness examinations are conducted as follows. First, substitute the variable of R\&D with input in R\&D currently and repeat the regression in Tables 4-6. And the result is same as before. Second, substitute the explained variable with stock price crash risk in the previous period, of which the result is same as before. Third, all the figure of controlled variables are substituted with that of in the previous period and repeat the regression in Tables 4-6, of which the results remain unchanged. Fourth, the heteroscedasticity of all regression analyses is not corrected and the result is still same as before. Robustness examination is not listed for saving space.

\section{Research Conclusion and Discussion}

This study examines the impact of corporate innovation behavior on stock price crash risk and makes a conclusion that corporate innovation indeed restrains stock price crash risk. With companies whose A share was listed between 2009 to 2015 as samples of the research, the influence of firms' input in R\&D on stock crash and the mechanism of action are explored in this dissertation. And a further study demonstrates that when facing financing constraints and information non-transparency, a firm's input in R\&D can reduce stock price crash risk, which is obvious in private and small enterprises and the condition without the audit of the Bog Four or little legal supervision. And the research in this dissertation enriches the existing documents about the relation between input in innovation and stock price crash risk.

There are some lessons we can learn from this research. First, the information disclosure of a firm's input in R\&D, which is important internal information, can reduce the risk of stock crash. Therefore, the system of information disclosure of R\&D should be improved and create more channels to disclose, which is helpful to maintain listed companies' market value, keep away financial risk so as to promote the stability of financial market. Besides, financing conditions and external supervision play an important role when input in R\&D's reduces stock price crash risk. So, enterprises should assess the financing conditions and external supervision on a regular basis and disclose $\mathrm{R} \& \mathrm{D}$ information in due course to remove the concerns of investors so as to raising enough capital, which not only contributes to the sound development of enterprises, but also is the requirement of China's innovation-driven development strategy.

\section{References}

Almeida, H., Campello, M., \& Weisbach, M. S. (2004). The Cash Flow Sensitivity of Cash. 
Journal of Finance, 59, 1777-1804. https://doi.org/10.1111/j.1540-6261.2004.00679.x

Barth, M., Kasznik, R., \& McNichols, M. (2002). Analyst Coverage and Intangible Assets. Journal of Accounting Research, 39, 1-34. https://doi.org/10.1111/1475-679X.00001

Bhattacharya, S., \& Ritter, J. R. (1983). Innovation and Communication: Signaling with Partial Disclosure. Review of Economic Studies, 50, 331-346. https://doi.org/10.2307/2297419

Chu, J., \& Fang, J. X. (2016). Margin-Trading, Short-Selling and the Deterioration of Crash Risk. Economic Research Journal, 5, 143-158.

Graham, J. R., Harvey, C. R., \& Rajgopal, S. (2005). The Economic Implications of Corporate Financial Reporting. Journal of Accounting and Economics, 40, 3-73. https://doi.org/10.1016/j.jacceco.2005.01.002

Hamdi, B.-N., Lobna, B., \& Rui, Z. (2017). Do Innovations Hoard Bad News? Evidence from Stock Price Crash Risk, Qatar: Qatar University.

Hsu, P., Lee, H.-H., Liu, A.-Z., \& Zhang, Z. (2015). Corporate Innovation, Default Risk, and Bond Pricing. Journal of Corporate Finance, 35, 329-344. https://doi.org/10.1016/j.jcorpfin.2015.09.005

Hutton, A. P., Marcus, A. J., \& Tehranian, H. (2009). Opaque Financial Reports, R2, and Crash Risk. Journal of Financial Economics, 94, 67-86.

https://doi.org/10.1016/j.jfineco.2008.10.003

Jiang, J. F., \& Wang, X. (2016). Schumpeter Competition, Cross-Effects, and Innovation Incentives. Journal of Management Sciences in China, 9, 79-93.

Jiang, X. Y., \& Xu, N. H. (2015). Corporate Over-Investment and Stock Price Crash Risk. Journal of Financial Research, 8, 141-158.

Jin, L., \& Myers, S. C. (2006). R2 around the World: New Theory and New Tests. Journal of Financial Economics, 79, 257-292. https://doi.org/10.1016/j.jfineco.2004.11.003

Kelm, K. M., Narayanan, V. K., \& Pinches, G. E. (1995). Shareholder Value Creation during R\&D Innovation and Commercialization Stages. Academy of Management Journal, 38, 770-786. https://doi.org/10.2307/256745

Kim, J.-B., \& Zhang, L. (2016). Accounting Conservatism and Stock Price Crash Risk: Firm-Level Evidence. Contemporary Accounting Research, 33, 412-441. https://doi.org/10.1111/1911-3846.12112

Kim, J.-B., Li, Y., \& Zhang, L. (2011a). Corporate Tax Avoidance and Stock Price Crash Risk: Firm-Level Analysis. Journal of Financial Economics, 100, 639-662. https://doi.org/10.1016/j.jfineco.2010.07.007

Kim, J.-B., Li, Y., \& Zhang, L. (2011b). CFOs versus CEOs: Equity Incentives and Crashes. Journal of Financial Economics, 101, 713-730. https://doi.org/10.1016/j.jfineco.2011.03.013

Lerner, J., \& Wulf, J. (2007). Innovation and Incentives: Evidence from Corporate R\&D. Review of Economics and Statistics, 89, 634-644. https://doi.org/10.1162/rest.89.4.634

Li, G., \& Liu, L. (2009). Debt Financing Cost and Private Credit Discrimination. Journal of Financial Research, 12, 137-150.

Li, W., \& Zheng, M. (2016). Is It Substantive Innovation or Strategic Innovation? Impact of Macroeconomic Policies on Micro-Enterprises Innovation. Economic Research Journal, 4, 60-73.

Li, X., \& Liu, H. (2012). CEO vs CFO: Gender and Stock Price Crash Risk. The Journal of World Economy, 12, 102-129.

Li, Y., \& Zhang, T. (2009). Evaluation of Financial Ecological Environment in China. Bei- 
jing, China Financial Publishing House.

Lin, L., \& Zheng, D. (2016). Delisting Regulation and Stock Price Crash Risk. China Industrial Economics, 12, 58-74.

Lu, Y., \& Huang, C. (2009). Study on the Market Response of R\&D Expenditure in High-Tech Industry. Science \& Technology Progress and Policy, 8, 60-63.

Lu, Y., \& Huang, G. (2009). Research on the Influencing Factors of R\&D Investment in High-Tech Industries. Science and Technology Management Research, 29, 197-200.

Luo, J., \& Du, X. (2014). Media Coverage, Institutional Environment and Stock Price Crash Risk. Accounting Research, 9, 53-60.

Ma, K., Tang, K., \& Hao, L. (2016). CPA Auditing and Capital Market Risk Prevention-Based on the Perspective of Stock Price Crash Risk. Journal of Shanxi University of Finance and Economics, 38, 25-34.

Pan, Y., Dai, Y., \& Lin, C. (2011). Information Opacity, Analysts Following and Stock Price Crash Risk. Journal of Financial Research, 9, 138-151.

Pang, S., \& Chen, D. (2009). A Study on the Relationship between R\&D Inputs and Patents. Studies in Science of Science, 10, 1500-1505.

Park, K. (2015). Financial Reporting Quality and Corporate Innovation. Working Paper, Boston, MA: University of Massachusetts.

Pietro, P., \& Wagenhofer, A. (2014). Earnings Quality Measures and Excess Returns. Journal of Business Finance and Accounting, 41, 545-571.

Qiao, J. (2003). R\&D of Public Companies and Information Asymmetry. Journal of South-Central University for Nationalities (Humanities and Social Sciences), 23, 53-55.

Tang, E., Wang, R., \& Liu, H. (2012). The Influence of Research and Development on the Profit of Enterprises-Based on the Analysis Angle of the Heterogeneity Productivity. Studies in Science of Science, 30, 124-133.

Wang, H., Cao, F., \& Ye, K. (2015). Monitoring or Tunneling? The Proportion of the Proportion Held by the Big Shareholders and the Risk of the Crash of the Stock Price. Management World, 2, 45-57.

Wang, Q., Zhang, J., \& Zhang, C. (2010). A Study on the Utility Patent Efficiency of R\&D Expenditure of China Innovative Enterprises. Science of Science and Management of S.\& T, 31, 5-12.

Wei, Z., Zeng, A., \& Li, B. (2014). Financial Ecological Environment and Corporate Financial Constraints-Evidence from Chinese Listed Firms. Accounting Research, 5, 73-80.

Wu, C., \& Tang, D. (2016). Intellectual Property Rights Enforcement,Corporate Innovation and Operating Performance: Evidence from China's Listed Companies. Economic Research Journal, 11, 125-139.

Xiao, H. (2007). Market Reaction and Its Impact of Related Factors on Chinese Listed Companies. Journal of Shanxi University of Finance and Economics, 10, 83-88.

Xie, D., Zheng, D., \& Cui, C. (2016). Is Controlling Shareholder's Share Pledge a Potential "Mine"? Management World, 5, 128-140, 188.

Xie, Z., \& Ai, C. (2014). Analyst Coverage and Corporate R\&D Investment: Analysis Based on Growth Enterprise Market in China. Journal of Finance and Economics, 40, 108-119.

Xin, Y. (2009). Research and Development Expenditure, Enterprise Performance and Market Reaction. Beijing: Chinese Academy of Fiscal Sciences.

Xin, Y. (2012). R\&d Expenditure, Enterprise Performance and Market Reaction. Beijing: Chinese Academy of Fiscal Sciences. 
Xu, M. (2016). Research on the Elasticity Relationship between Patent Application and R\&D Input Factors: The Empirical Study on the Panel Data of Thirty-Six Industries. Science of Science and Management of S. \& T., 1, 30-37.

Xu, N., Jiang, X., Yi, Z., \& Xu, X. (2012). Conflicts of Interest,Analyst Optimism and Stock Price Crash Risk. Economic Research Journal, 7, 127-140.

Xu, N., Li, X., Yuan, Q., \& Chan, K. C. (2014). Excess Perks and Stock Price Crash Risk: Evidence from China. Journal of Corporate Finance, 25, 419-434.

Yao, K., Tang, J., \& Jiang, Y. (2013). R\&D Input, R\&D Project Progress and Fluctuation of Stock Price. Chinese Journal of Management Science, 11, 205-213.

Yao, K., Tang, J., \& Jiang, Y. (2013). R\&D Input/R\&D Project Progress and Fluctuation of Stock Price. Chinese Journal of Management Science, s1, 205-213.

Zhang, R., Xue, H., \& Zhao, J. (2017). Managerial Self-Serving, Supervision and Management Earnings Forecasts Bias. Accounting Research, 1, 32-38, 95.

Zhang, Y. (2006). Study on the Economic Effect of Manufacturing R\&D Investment. China Science and Technology Information, 5, 175-175. https://doi.org/10.1007/s11432-006-0175-y

Zheng, Y., Chen, C., \& Ren, H. (2016). Patent Activities and Market Value: An Explanation Based on Signaling Theory. Science of Science and Management of S. \& T., 3, 68-78. 